\title{
Edmodo as Web-Based Learning to Improve Student's Cognitive and Motivation in Learning Thermal Physics
}

\author{
Pia Fildzah Vania1, Wawan Setiawan², Agus Fany Chandra Wijaya ${ }^{3 *}$ \\ ${ }^{1}$ Department of Science Education, Faculty of Mathematics and Science Education, Universitas Pendidikan Indonesia, Indonesia \\ ${ }^{2}$ Department of Computer Science Education, Faculty of Mathematics and Science Education, Universitas Pendidikan Indonesia, \\ Indonesia \\ ${ }^{3}$ Department of Physics Education, Faculty of Mathematics and Science Education, Universitas Pendidikan Indonesia, Indonesia
}

*Corresponding Author. agus ipba@upi.edu

\begin{abstract}
This research aims to investigate the use of Edmodo as web-based learning in learning thermal physics in junior high school. The analysis of this research focused on students' cognitive and motivation in the classroom. The method used in this research was quasi-experiment with the pretest-posttest design. One class taken as a sample in this research comes from one of an international school in Padalarang. The quantitative data of this research was gained through the objective test (pretestposttest) based on Bloom's Taxonomy and questioner of motivation based on ARCS Motivational Design. Data processing was done by SPSS 20.0. The result of this research shows that there is an improvement of student cognitive C2 until C5 after learning using Edmodo. The average score in pretest was 45.89 and improve to 72.63 . The result of normalized gain was 0.49 , it included as a medium improvement. Edmodo also increases student motivation in learning thermal physics.
\end{abstract}

Keywords Web-based Learning, Edmodo, Thermal Physics, Students' Cognitive, Students' Motivation, ARCS Model

\section{INTRODUCTION}

Technology always develops every time, technology helps us to do everything, even in education. Technology today can influence the education system, the way of teaching and how a student gets the information. Using technology hopefully can make every student has a chance to get a proper education. The current generation of students, commonly referred to as "NetGen" learners, grew up surrounded by technology and bombarded by continuous technological advancements. Computers, multimedia, the Internet, cell phones, and computer games were and continue to be a central and intuitive part of their life (Pergola \& Walters, 2011). That situation did not happen in all school, some school has not yet used technology in their learning process. In Indonesia, only some school has integrated the learning process and technology using the internet.

The development of multimedia technology has changed the way people learn, obtain various information as well as in interpreting information (Ziden \& Rahman, 2013). The use of the interactive learning environment begins with an instructor uploading a set of lecture slides and setting up an interactive Lethe morning session. This task may include adding quiz questions and the lecture session preferences prior to entering the classroom. The instructor has an expanded user interface that provides access to these administer rating functions such as uploading slideshows, creating quizzes, and enabling or disabling in interactive features (Chao, Parker \& Fontana, 2011). A student can access the materials or information every time and everywhere as long as there is an internet. This is a good idea if we develop this concept into Indonesia education system because children in Indonesia can access the materials before they come into the classroom.

In learning science concept, sometimes the student find difficulty in learning. By using this web-based learning, the student can choose the time to learn and they can use their own gadget to access the materials. Web-based learning also can increase the student motivation in learning. Today, some student lazy to learn because the traditional method that uses is not matched with the development of technology. The previous work has been conducted in

Received: 29 June 2018

Revised: 2 August 2018

Published: 11 August 2018 
order to improve students' motivation. Prima, Putri, \& Rustaman (2018) implemented PhET simulation during learning solar system. Putri, Rusyati, \& Rochintaniawati (2018) conducted problem-solving model in learning heat to improve students' motivation. In this research, the authors will find out the use of Edmodo towards student cognitive and motivation while learning thermal physics. Edmodo is an educational technology that the teacher, student, and parent can use. By this application, the teacher can share information, materials of teaching, a task for the student, and also an exam.

The teacher can track student performance and give a score to the student. The student can access the materials every time, chat with their friends and doing online quiz. This research will try to measure student students' cognitive that is measured in this research involves level cognitive, understanding (C2), applying (C3) and analyzing (C4) based on Taxonomy Bloom (Anderson, et. al., 2001).

To teach thermal physics, Edmodo can be used as an additional media, the teacher can put all materials on the Edmodo and the student can access it before starting the class or at home. In this topic, the teacher will do some classroom activity and quiz. There are some sources that the teacher will put in Edmodo, there are video, articles, question, and quiz. The teacher will ask the student to access Edmodo before coming to the classroom. A student can easily access the source of the lesson and can repeat it every time a student need. There are several advantages if the teacher uses Edmodo than the other media, Edmodo is easy to use for teacher and student, the teacher can put a note, quiz, polling, alert and student can access it every time. By using Edmodo, it is expected that the student can improve their motivation as well as the student cognitive in learning thermal physics.

\section{METHOD}

This research using the quasi-experiment method, According to Fraenkel \& Wallen (2007), the weak experimental design does not have built-in controls for the threat to internal validity. In addition to the independent variable, there are a number of other plausible explanations for any outcomes that occur. This research design using
One-Group Pretest-Posttest Design according to Fraenkel \& Wallen (2007).

The location of this research was in one international school in Bandung Barat. The school used Cambridge curriculum combine with 2006 Curriculum of Indonesia. This school using English as the main language in the teaching-learning process. The population in this research was 7th-grade students. The sample was one class in seventh grade. The sample was all of cognitive abilities and motivation on a thermal physics chapter in one class. Sampling was selected by purposive sampling technique.

\section{RESULT AND DISCUSSION 3.1 Implementation of Edmodo}

The implementation of Edmodo conducted both in school and at the home. In school, the student got materials about thermal physics using traditional method combine with Edmodo as shown in Table 1 about the learning scenario. The implementation of Edmodo was conducted in five meeting. The result of implementation Edmodo can be seen in the activity in Edmodo and in the classroom. In the classroom, the student can access Edmodo using handphone and laptop. They should bring this media to access Edmodo in the classroom. The other result can be seen from student activity in Edmodo. The student can access Edmodo to see the materials and doing exercise or quiz. The student can see their score and performance in their own profile.

In the implementation of Edmodo, the researcher found some effect of Edmodo, the effect can be positive and also negative. In the first meeting of Edmodo implementation, the students are interested in Edmodo and asking many things about it. The teacher distributed Booklet how to use Edmodo so the students can learn and use it at the house. Edmodo also was used as media for the students doing pre-test at home. They are accessed Edmodo and doing their own pre-test at home, while they doing the pre-test, some students found the difficulty while doing their first pre-test. There is some reason that can make the student difficult while doing it, there are, the student cannot get internet access at home, the student inadvertent click did so their score is zero, and the student did not see the time limitation while doing a pre-test. For

Table 1 Learning activity

\begin{tabular}{|c|c|c|}
\hline Date & School activity & Home activity \\
\hline Day 1 & $\begin{array}{l}\text { - Distribute booklet to the student } \\
\text { - Ask the student to Login \& Doing pre-test }\end{array}$ & - Doing pre-test \\
\hline Day 2 & $\begin{array}{l}\text { - Introduction to thermal physics } \\
\text { - Learning-process in the classroom }\end{array}$ & $\begin{array}{l}\text { - Doing Exercise } \\
\text { - Reading PowerPoint about the thermometer }\end{array}$ \\
\hline Day 3 & - Learning-process in the classroom & $\begin{array}{l}\text { - Reading PowerPoint about thermal capacity } \\
\text { - Learning worksheet calorimeter }\end{array}$ \\
\hline Day 4 & - Laboratory activity: Calorimeter & - Announcement about post-test \\
\hline Day 5 & - Post-test & \\
\hline
\end{tabular}


the student for that reason, the teacher giving the same question but using a paper test.

In the school, the students learn as usual but combine with Edmodo. The role of the teacher cannot be replaced with Edmodo, the teacher still need to guide the student in the classroom. In the second meeting, the student brings their own laptop and handphone to the classroom so they can access Edmodo in the class. The teacher also checks student problems while they're using Edmodo at their home. In Edmodo, the teacher put exercise that student must fill in the classroom. At the end of the class, the teacher announces student to access Edmodo at home and see the next topic, so they can learn at home.

The teacher also combines the learning process in the classroom using classroom activity and laboratory. In the third meeting, the teacher continues teaching in the classroom and put the materials in Edmodo as usual. The teacher also put worksheet calorimeter for the student. The student should learn the worksheet before comes to the laboratory.

In forth meeting, the teacher asks the student to bring their own handphone and laptop to see and fill out the worksheet. Some student also found the problem while doing this, some student that did not have pdf application cannot open the worksheet using their own handphone but since this laboratory was grouped assignment, so the student can share their phone and laptop with their friends. The last meeting used to post-test and fill motivation questioner.

\subsection{Student Cognitive}

Student cognitive in this research is obtained by using multiple choice questions based on the level of cognitive by blooms taxonomy. This test is given to the student before learning (pre-test) using Edmodo and after learning (post-test) after learning using Edmodo. This test used to measure the improvement of student cognitive towards the implementation of Edmodo as web-based learning in

Table 2 Summary of student cognitive result

\begin{tabular}{cccccc}
\hline No & Component & $\begin{array}{c}\text { Pre- } \\
\text { test }\end{array}$ & $\begin{array}{c}\text { Post- } \\
\text { test }\end{array}$ & $<\mathrm{g}>$ & Category \\
\hline 1 & Participant & \multicolumn{2}{c}{27} & & \\
2 & Max score & \multicolumn{2}{c}{100} & & \\
3 & $\bar{X}$ & 45.89 & 72.63 & 0.49 & Medium \\
4 & Lowest score & 5.6 & 44.4 & & \\
5 & Highest score & 77.8 & 100 & & \\
\hline
\end{tabular}

learning thermal physics are pre-test and post-test. The parameter that used was revised of Bloom's cognitive domain from $\mathrm{C} 2$ until C4. C2 is the representative of the low cognitive level and C3 until C4 as representative of the high cognitive level.

The improvement of student cognitive was determined by calculating the score of normalized gain $\langle\mathrm{g}\rangle$. The normalized gain value was processed through data of pretest and post-test score which has been executed by all participant students. The result of the normalized gain $\langle\mathrm{g}\rangle$ calculation is presented in Table 2. It can be seen that the score of the student has increased from 45.89 to 72.63 . The result comes from 27 samples. Data pre-test taken before the student get treatment meanwhile the data of post-test collected after a student got treatment using Edmodo. There were 18 questions that distributed into learning objective in thermal physics. The standard deviation was 2.915 for pre-test and 3.121 for post-test. N-gain score from this research was 0.49 . The normalized gain results as much as 0.49 . Based on Hake's index it included as a medium category of improvement.

To analyze the whole improvement profile of student cognitive, the instrument was designed to interpret the student's capability in a cognitive domain based on Bloom's taxonomy. There are three different level of cognitive that used in this research. Start from C2 (Understanding), C3 (Applying); C4 (analyzing). The result of each cognitive domain from student answer in pre-test and post-test is shown in Table 3. The improvement of the student in each domain got medium category based on Hake (1999). The preliminary objective test has been conducted to see the validity, reliability, discriminating power and difficulty level of the objective test.

Each cognitive level has a different result, the biggest significant difference is in C4 (Applying) Cognitive level, after that C3 (Applying). Generally, all the cognitive level showing the improvement between pre-test and post-test.

Table 4 The summary of student's statistical test

\begin{tabular}{ll}
\hline Components & Results \\
\hline Kolmogorov-Smirnov & Sig. $\geq 0,05=$ Normal \\
Normality test & 0.110 \\
Sig. & Normal \\
Conclusion & (Asymp sig $\left(2-\right.$ tailes) $<0.05, \mathrm{H}_{0}=$ \\
Wilcoxon test & Rejected) \\
Sig. & 0.001 \\
Conclusion & $\mathrm{H}_{0}$ Rejected $\mathrm{H}_{1}$ Retained, \\
\hline
\end{tabular}

Table 3 Recapitulation of student cognitive domain based on Bloom's taxonomy

\begin{tabular}{cccccccc}
\hline $\begin{array}{c}\text { Cognitive } \\
\text { Domain }\end{array}$ & $\begin{array}{c}\text { Amount of } \\
\text { Question }\end{array}$ & Participants & $\begin{array}{c}\text { Max } \\
\text { Score }\end{array}$ & Pre-test & Post-test & $<$ g> & Category \\
\hline C2 & 8 & & & 54.16 & 74.07 & 0.43 & Medium \\
C3 & 4 & 27 & 100 & 36.11 & 66.66 & 0.47 & Medium \\
C4 & 6 & & & 41.97 & 74.69 & 0.56 & Medium \\
\hline
\end{tabular}


To determine whether the hypothesis is accepted or rejected, the normality and Wilcoxon test were conducted. The summary of normality and Wilcoxon is shown in Table 4. It shows that the normality test (Kolmogorov-Smirnov) has 0.110 (Sig. $\geq 0.05=$ Normal) that is mean that the result is normal and possible using parametric statistic. To use parametric statistics, the normality should be Sig. $\geq 0,05$, but the samples that taken should be more than 30 samples. In this research, there are 27 samples that are mean less than 30 and this research cannot use parametric statistics. Samples that less than 30 will use non-parametric statistic, this research use one classroom as a control class and experiment class, Wilcoxon test was chosen because of that reason. In Wilcoxon test, the significant difference that resulted in 0.001 (Asymp sig $(2-$ tails) $<0.05)$ that is mean $\mathrm{H}_{0}$ Rejected and $\mathrm{H}_{1}$ Retained, or there is a difference of students cognitive and students' motivation in learning thermal physics using Edmodo as Web-Based Learning.

The implementation as treatment of Edmodo has been conducted in five meeting in the classroom and Edmodo also accessed by the student at home, the pre-test as well as post-test. Pre-test and post-test showed the improvement of student score. The average score of pre-test was 45.89 and post-test was 72.63 the normalized gain of this research was 0.49 and based on Hake (1999) is included in the medium category. Using the educational networks as integration in teaching has a positive effect on secondary school students (Nee, 2014).

The use of Edmodo is not only in the classroom, the implementation of Edmodo also conducted out of school or at home. In the first meeting, the student got the induction and guiding book. The student should read the materials of learning before coming to the classroom in Edmodo also doing a pre-test. Pre-test conducted in Edmodo, the student has a deadline to do the pre-test. Some students found the difficulty while doing pre-test using Edmodo. They said that they cannot turn in the test. More than half student finished pre-test in Edmodo, the other doing pretest in the classroom because of the due of the pre-test. In a traditional classroom, students concentrate on school learning, the learning time and space are greatly restricted. In the educational network, all resources are shared on the network at any time and anywhere (Nee, 2014).

In the first meeting, the student interest with Edmodo, they were asking how to use it, how they score will be upload. The students feel exciting while they know they can bring their own handphone into the classroom. A combination of traditional in-class instruction and an online classroom community via Edmodo is significantly verified to be an effective factor in generating more positive attitudes.

In the implementation of Edmodo, some student cannot answer the pretest. The question in pre-test comes from 11 learning objective and has been tested before the test giving to the student. The difficulty level of the question also arranged before the question uploaded to Edmodo. The question can be easy, medium and difficult. In the result, most of the score of pretest lower than the standard score at school. The student who do pre-test never learn thermal physics concept before, maybe just some indicator that taught in elementary school such as a thermometer. At the end of the class, the teacher giving the task to access Edmodo and see what will be learned tomorrow. There is some factor that can make the student has a low score, the factor can be from internal and from external. For the student that did not have willing to learn, the score of student can be lower than standard.

Learning situation force the student to study at home and improve their performance. Learning materials are available anytime and anywhere. That can increase their motivation to gain more score. A teaching method that used in this experiment was expository and lecturing, the student got homework in Edmodo, it forces them to accessed Edmodo at home. In the school student can bring their own handphone or laptop to access Edmodo. Handphone is one of the media to access Edmodo, they can access learning materials in the classroom. That kind of situation can stimuli the student to have a higher score in their post-test. Technology helps the student find another way to learn.

In the classroom, the student activities in asking and answering teacher question about thermal physics. They were willing to learn. In laboratory activity about calorimeter, the students access the procedure and question in Edmodo. They collected the answer in a paper.

From the point of view of cognitive theory domain, the implementation of Edmodo has increased their cognitive domain. In each cognitive domain, there was an improvement, the improvement of the cognitive domain because the student has already got the materials of thermal physics. The student learns at school and at home, it increases their knowledge about thermal physics, which is the reason they can increase their performance but, some student did not improve their score.

Based on the Wilcoxon test, the value is 0.001 that means hypothesis $\mathrm{H}_{0}$ was rejected, so there was the significant difference after learning using Edmodo. Edmodo was helping the teacher to give the source to the student, to make a student learn at home and make the student increase their score. 


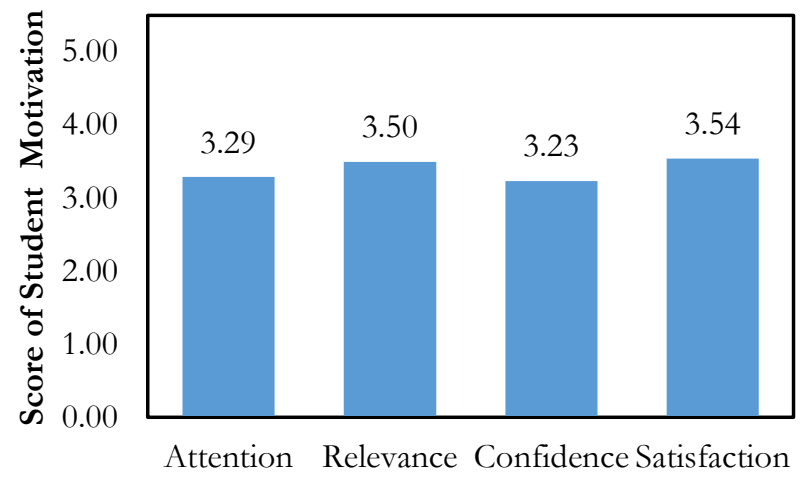

Situation based on ARCS Model

Figure 1 Comparison ARCS situation

\subsection{Student Motivation}

The second variable in this research is student motivation towards learning thermal physics using Edmodo. The data of student motivation collected from questioner of motivation, ARCS model motivational design by Keller (2000). Keller (2000) arranged 36 questioners into four situations, there are attention, relevance, confidence, and satisfaction. Each number has its own score. The result of student motivation questioner present in Table 5.

According to Table 5, in each condition, the student felt motivated enough. Attention has average score 3.28, means that the student giving attention while learning in the classroom and they are willing to invest their time, pay attention, and find out more (Poulsen, Lam, Cisneros \& Trust, 2008). Relevance has an average score of 3.49, this score higher than attention condition, same with attention, relevance also showing that student has been motivated enough but in different condition. The third one is confidence, the score was 3.23 this was the lowest score compared with the other condition. The score means that the expectations of the student was good, and feel motivated. The last condition is satisfied, in satisfaction, the average score was 3.54 this was the highest score in the condition that means that student motivated. And in the last column, the average from all categories, the average score of ARCS was 3.38 from the maximum score was 5 . This means that the student motivated enough. The analysis will do in each situation.

Comparison of each situation based on a score that gains by each condition shown in Figure 1. Satisfaction shows the highest part. The implementation of Edmodo in the classroom can affect student motivation in learning. Motivation refers to the reasons individuals take action. Motivation to learn willingness or desire to gain information, develop skills and attain mastery (Blazer, 2010). Their interest in learning with this kind of software was greater than their interest in learning in the traditional
Table 5 Average score in each condition

\begin{tabular}{lcl}
\hline \multicolumn{1}{c}{ Condition } & Average & \multicolumn{1}{c}{ Definition } \\
\hline Attention & 3.28 & Motivated enough \\
Relevance & 3.49 & Motivated enough \\
Confidence & 3.23 & Motivated enough \\
Satisfaction & 3.54 & Motivated \\
ARCS & 3.38 & Motivated enough \\
\hline
\end{tabular}

classroom (Wang \& Reeves, 2007). Many students are not motivated to learn in the classroom (Blazer, 2010).

To see student motivation, this research used the ARCS model by Keller (2000). To see student motivation also can be seen from student post-test score. Motivated student earns higher grades and achievement test scores than the extrinsically motivated student (Blazer, 2010). The analysis of student motivation was conducted in general and also personal. The data from student motivation questioner were processed using Microsoft Excel 2010. The score from each situation is calculated to find the mean of each situation. The highest improvements are shown in relevance condition while the lowest improvement is shown in the attention and satisfactory condition. The result comes from calculating the average score of a combination of positive and negative criteria for each condition, then determine the categories with the provisions of the average score.

The first category was attention, the average score of attention was 3.28 , with percentage $60.68 \%$, that was mean that teacher can get class attention and defend it, the student was motivated enough to learn. It is really possible since this is the first time for student used Edmodo in the classroom. Usually, the teacher teaches the student using the traditional method, since teacher trying using Edmodo in the classroom, the teacher can get student attention and increase student motivation in learning science. The potential that technology offers to positively affect student achievement is sufficient reason to integrate technology as a means to motivate students to learn (Heafner, 2004).

The second category was relevance, the average score of relevance was 3.49, and the percentage was $69.9 \%$. The score means that the teacher can give the example that related to daily life. This score means that the student motivated to learn because of the learning materials related to daily life. While learning in the classroom, teacher showing example that related to daily life, the teacher also provides several things that familiar with the student like a thermometer. In learning thermal physics, a teacher showing the video about children that got the fever to guide the student find the function of a thermometer.

The third one was confidence. The average score of this categorize was 3.23 , this includes in motivated enough. The percentage was $64.6 \%$, confidence means that teacher should trust the student and give student believes. The teacher can motivate the student to improve their performance. Teacher showing the Edmodo in the last session of the meeting, the teacher show student score to 
increase their motivation to gain more and to participate more in Edmodo and in the classroom.

The last categorize was satisfaction, the score of satisfaction was 3.58 , this is the highest score among all categories, this score included as motivated. The percentage of this categorize was $62.9 \%$. Satisfaction means that the student feeling satisfied after got high score or achievement. After the teacher showing the score in Edmodo, some student that got a high score express their happiness in the classroom, they are feeling satisfied with their result. These conditions in the classroom increase another student to gain more score. They were asking about the question that they cannot answer while doing a pre-test.

\section{CONCLUSION}

The implementation of Edmodo as web-based learning has been conducted systematically. It is acquired some conclusions as follows. First, the implementation of Edmodo in the classroom resulted in a positive effect on student cognitive and student motivation. Second, the implementation of Edmodo as web-based learning in learning thermal physics can improve student cognitively, can be noticed by the results of each cognitive level that increase from pre-test to post-test and also the normalized gain is shown medium improvement. Third, the implementation of Edmodo also affected student motivation in learning thermal physics, this can be noticed from the result of student motivation questioner. The result from the motivation questioner included as satisfied motivated.

\section{REFERENCES}

Anderson, L. W., Krathwohl, D. R., Airasian, P. W., Cruikshank, K. A., Mayer, R. E., Pintrich, P. R., ... \& Wittrock, M. C. (2001). A taxonomy for learning, teaching, and assessing: A revision of Bloom's taxonomy of educational objectives, abridged edition. White Plains, NY: Longman.

Blazer, C. (2010). Twenty Strategies to Increase Student Motivation. Information Capsule. Research Services, Miami-Dade County Public Schools. 0907.

Chao, J. T., Parker, K. R., \& Fontana, A. (2011). Developing an interactive social media based learning environment. Issues in Informing Science and Information Technology, 8, 323-334.

Fraenkel, J.R., \& Wallen, N.E. (2007). How To Design and Evaluate Research in Education, Sixth Edition. New York: Mc Graw Hill.

Hake, R. R. (1999). Analyzing change/gain scores. Unpublished.[online] URL: http:// www. physics. indiana. edu/ sdi/AnalyzingChange-Gain. $p d f$.

Heafner, T. (2004). Using technology to motivate students to learn social studies. Contemporary Issues in Technology and Teacher Education, 4(1), 42-53.

Keller, J. M. (2000). How to integrate learner motivation planning into lesson planning: The ARCS model approach. VII Seminario, Santiago, Cuba, 1-13.

Nee, C. (2014). The effect of educational networking on students' performance in biology. In TCC Worldwide Online Conference (pp. 7397). TCCHawaii.

Pergola, T. M., \& Walters, L. M. (2011). Evaluating Web-Based Learning Systems. Journal of Instructional Pedagogies, 5.

Prima, E. C., Putri, A. R., \& Rustaman, N. (2018). Learning solar system using PhET simulation to improve students' understanding and motivation. Journal of Science Learning, 1(2), 60-70.

Poulsen, A., Lam, K., Cisneros, S., \& Trust, T. (2008). ARCS model of motivational design. Retrieved March, 21, 2011.

Putri, A. U., Rusyati, L., \& Rochintaniawati, D. (2018). The Impact of Problem-Solving Model on Students' Concept Mastery and Motivation in Learning Heat Based on Gender. Journal of Science Learning, 1(2), 71-76.

Wang, S. K., \& Reeves, T. C. (2007). The effects of a web-based learning environment on student motivation in a high school earth science course. Educational Technology Research and Development, 55(2), 169192.

Ziden, A. A., \& Rahman, M. F. A. (2013). The Effectiveness of WebBased Multimedia Applications Simulation in Teaching and Learning. International Journal of Instruction, 6(2), 211-222. 